\title{
Unveiling the Public Procurement Market in Brazil: a methodological tool to measure its size and potential
}

DOI:

10.1111/dpr.12301

\section{Document Version}

Accepted author manuscript

Link to publication record in Manchester Research Explorer

\section{Citation for published version (APA):}

Ribeiro, C. G., Inácio, E., Raun, A. T., \& Li, Y. (2017). Unveiling the Public Procurement Market in Brazil: a methodological tool to measure its size and potential. Development Policy Review.

https://doi.org/10.1111/dpr.12301

\section{Published in:}

Development Policy Review

\section{Citing this paper}

Please note that where the full-text provided on Manchester Research Explorer is the Author Accepted Manuscript or Proof version this may differ from the final Published version. If citing, it is advised that you check and use the publisher's definitive version.

\section{General rights}

Copyright and moral rights for the publications made accessible in the Research Explorer are retained by the authors and/or other copyright owners and it is a condition of accessing publications that users recognise and abide by the legal requirements associated with these rights.

\section{Takedown policy}

If you believe that this document breaches copyright please refer to the University of Manchester's Takedown Procedures [http://man.ac.uk/04Y6Bo] or contact uml.scholarlycommunications@manchester.ac.uk providing relevant details, so we can investigate your claim.

\section{OPEN ACCESS}




\title{
UNVEILING THE PUBLIC PROCUREMENT MARKET IN BRAZIL: A METHODOLOGICAL TOOL TO MEASURE ITS SIZE AND POTENTIAL $^{* \dagger}$
}

\author{
Authors: Cássio Garcia Ribeiro (IE - UFU), cassiogarcia@ufu.br \\ Edmundo Inácio Júnior (FCA - Unicamp), edmundo.inacio@fca.unicamp.br \\ André Tortado Raun (IPEA), andrerauen@gmail.com \\ Yanchao Li (MIOIR - The University of Manchester), yanchao.li@mbs.ac.uk
}

\begin{abstract}
Public procurement plays a key role, both in the proper functioning of public administration and in the realization of broader policy objectives. This article aims to present a methodology to assess the Brazilian public procurement market based on governmental statistics, as well as reflect on the potential of public procurement policy for the development of the country. The paper found that public procurement took up an average of $13.8 \%$ of the Brazil GDP during 2006-2012. The Brazilian public procurement market is comparable to that of a typical OECD country. These findings imply great potential for public procurement in Brazil as a policy instrument for promoting the country's development.
\end{abstract}

\footnotetext{
* We are thankful to the anonymous referees for the contributions.

† The authors would like to say thank to InSySPo - Innovation Systems, Strategies and Policy, Sao Paulo Excellece Chair (SPEC) programme funded by the Research Foundation of the State of Sao Paulo (FAPESP) under the International Workshop - UK - Sao Paulo Early Career Researcher: Science, Technology and Innovation Systems: Dynamics, Governance and Public Policy held by the Department of Science and Technology Policy at 03-06 March 2015, Campinas, São Paulo, Brazil for financial support.
} 


\section{Introduction}

Public procurement, or government procurement, is the acquisition of goods and services by the public sector from third parties (Arrowsmith, 2010). Primarily public procurement provides the inputs necessary to fulfil government functions. Moreover, the public procurement market is responsible for a significant percentage of a country's GDP, thus creating a direct impact on the national economy. Public procurement has a significant role regarding the promotion of domestic industries, social equality, environmental protection, small and medium enterprises development, and more recently, technology and innovation development (Edquist et al., 2015).

According to Thai,

Although public procurement is perceived as a major function of government, and although governmental entities, policy makers and public procurement professionals have paid a great deal of attention to procurement improvements or reforms, public procurement has been a neglected area of academic education and research (2001: 10).

Given that public procurement can be associated to multiple objectives (such as the efficiency of public administration, improving the delivery of public services to society, promoting specific sectors, stimulating technological innovation, among others), it is essential for the public sector to have access to detailed information about such market. The existence of complete and detailed information about this market helps in assessing efficiency and effectiveness of public procurement. Moreover, it should be emphasized that the issue of public procurement is often part of international multilateral agreements in the scope of Word Trade Organization (WTO) treaties (Guimarães, 2003). Therefore, having access to disaggregate data on the public procurement market allows the federal government, for instance, to rethink its policies, paths, mechanisms and strategies with international trade partners.

In Brazil, there are few studies aiming to measure the size of public procurement market in the country. The works by (Marques, 2005) and by (Ribeiro, 2009) are the only ones that deal with the subject. However, in both cases, there is no detailed information about how to measure the size of public procurement across the different government levels in Brazil. On the other hand, there is no precise official account of public procurement in Brazil. In fact, this has been a major concern in the recent public policy agenda. 
Therefore, the objective of this article is to present and discuss, in detail, a methodology to measure the Brazilian public procurement market. Such methodology will be applied to reveal the size of this market according to two main dimensions, the three levels of government, as well as between current expenses and the acquisition of fixed capital. The methodology is based on the following instruments: i) systematic review of the literature; ii) documentation research: analysis of laws, reports and manuals, etc.; and iii) analysis of secondary data from four databases, namely: Finanças Brasil (FINBRA Finance Brazil) for states and municipalities, the SIAFI ${ }^{3}$ Gerencial and the annual report from the Ministério do Planejamento, Orçamento e Gestão (MPOG - Ministry of Planning, Budget and Management), entitled "Budget Execution of State-owned companies”, for the federal government.

The rest of the paper unfolds as follows. In the next section, we present a review of the literature concerning the issue of the public procurement and its various policy functions. Then, we move on to discuss the efforts and difficulties in measuring the public procurement market. Section four presents and applies the methodology proposed. Finally, section five sums up the main conclusions and point out some new research questions.

\section{Public procurement: concepts, rules and objectives}

The term public procurement ${ }^{4}$ refers to purchases of goods and services made by a country's public sector, with the different levels of State taken into consideration. Public purchases are made to ensure the operations of the public administration and provide services to society in various areas such as education, healthcare, security, energy and infrastructure (Kashap, 2004).

Simply, public procurement can be conceptualized as a formal procedure whereby government agencies obtain goods and services, including construction services or public works. It also covers the description of requirements, the selection of providers, evaluation of offers, preparation and award of contracts, settling disputes and claims, and all stages of

\footnotetext{
${ }^{3}$ Siafi is the integrated system of Financial Administration in the Federal Government of Brazil. It is the main instrument used for recording, monitoring and control of budget implementation, financial and assets of the Federal Government.

${ }^{4}$ According to Arrowsmith (2010, p. 1) "Public procurement is the phrase generally used now to refer to this activity in the English language in the EU since it is the phrase used in EU legislation. However, other systems use different terminology to cover the same concept - for example, the World Trade Organization system refers to 'government procurement' and the US system, generally, to government contracts or public contracts”. In this paper we chose to use the phrase public procurement.
} 
the administration of a contract.

Because of its importance, public procurement is also subject to supranational rules besides national rules (related to procedures, scope, values, institutions and items covered). The touchstone of the rules of this is non-discrimination. None of their Contracting Parties shall treat less favorably the products, services and suppliers of other Member States, in relation to its products and services. Furthermore, there should be no discrimination of products, services and suppliers of a Member State to another and each Contracting Party shall ensure that its government agencies do not give less favorable treatment to a national supplier in relation to other national supplier, based on foreign ownership in these companies (Kashap, 2004).

It is possible to identify some barriers to open markets for public procurement, from which it is possible to understand the reluctance of some countries (such as Brazil) in joining supranational arrangements, such as: communication problems, exchange rates and payment, customs rules, waiting time, foreign government regulations, and transportation (Thai, 2001). In addition, adherence to supranational agreements can derail or hinder the use of public purchase power to achieve objectives such as economic, social and technological development, since these agreements do not allow preferential treatment to domestic companies, with some exceptions.

With regard to the importance of public procurement policy, firstly, it is relevant to remember the magnitude of public market. Virtually in all countries, the government is a major purchaser in the national economy. In this sense there is a very large economic potential related to purchases of goods and services performed by the public sector of a country, but at the same time, great challenges to avoid having problems arising from these acquisitions (such as waste, corruption etc.). According to Thai,

...in developed as well as developing countries, disregarding their economic, social, and political environment, a sound procurement system seems to have two groups of goals: procurement goals and nonprocurement goals. The procurement goals normally include quality, timeliness, cost (more than just the price), minimizing business, financial and technical risks, maximizing competition, and maintaining integrity. Non-procurement goals normally include economic goals (preferring domestic or local firms), environment protection or green procurement (promoting the use of recycled goods), social goals (assisting minority and woman-owned business concerns), and international relations goals. It is very difficult for policy makers and public procurement professionals to make an optimum decision as there are always tradeoffs between these goals (2001: 3). 
Regarding procurement goals, we can see a major effort on the part of legal frameworks (national and supranational) to strengthen the integrity, transparency and efficiency of the acquisitions made by the State (Arrowsmith, 2010, Thai, 2001). First, with regard to the transparency attribute, it is important to draw attention to the fact that corruption is one of the great scourges of public administration in many countries (regardless of their stage of development) (OCDE, 2010).

Corruption can be classified as a government failure (Mendoza and Thelen, 2008) and in the case of public procurement can manifest in the form of bribes paid or received for the award of contracts for goods or services. As corruption is a widespread problem, resulting of obsolete systems characterized by opportunities for abuse (Mendoza and Thelen, 2008), the legal framework governing public procurement should deal with this issue. In this sense, the laws of the countries should assist in creating devices that inhibit morally reprehensible behavior (such as overpricing of public works and the payment of bribes), punishing severely those involved, criminal and economic point of view (imposing fines and obligations in terms of loss recovery caused to the public treasury).

Still on the subject procurement goals, Arrowsmith (2010) points out that one of the most important targets of public procurement systems is the acquisition of goods and services under the best possible conditions. Therefore, efficiency, in terms of agility and economy of resources, is in many cases one of the attributes pursued by public procurement. In this sense, the laws of the countries that govern the public procurement in many cases rely on bidding procedures and rules that aim to ensure the efficiency of the purchase. Arrowsmith (2010: 6) lists three aspects that must be considered with regard to the objective of efficiency in public procurement:

- Ensuring the goods, works or services acquired are suitable. This means both: i) that they can meet the requirements for the task in question and ii) that they are not overspecified ("gold-plated");

- Concluding an arrangement to secure what is needed on the best possible terms (which does not necessarily mean the lowest price);

- Ensuring the contracting partner is able to provide the goods, works or services on the agreed terms.

Following the classification proposed by Thai (Thai, 2001), with regard to non- 
procurement goals, it is possible to identify the use of public procurement for the achievement of objectives in terms of social, economic, technological and, environmental development. The United States represent a country whose legal framework favors social development via public procurement. The Small Business Act (SBA) requires that all purchases of goods and services and public works contracts of value between US\$2,500 and US\$100,000 are automatically aimed at small businesses, in addition to giving preference to people and social groups in economic and social disadvantage. In order to ensure compliance with these determinations by the organs and public companies, stringent mechanisms were created for monitoring and evaluating bidding processes. It is important to highlight that the preference policy for small businesses established in the Small Business Act, cannot be waived by international agreements signed by the United States. Soon, there is a strong restriction on the entry of foreign companies in American Government procurement market (Thai, 2009).

With regard to the use of public procurement policy to achieve objectives that go beyond the social development (such as economic development, industrial, technological and environmental), fits to emphasize that the purchases made by the public sector are one of the direct channels through which the government interferes in the aggregate demand, intervening directly the economy. In deciding to use its procurement power to stimulate the domestic production of certain goods and services, the public sector in some cases, must pay a premium in exchange for the development of local industry. Due to the growing competition observed in different markets, high costs and risks associated with innovative activities, the shortening of life cycles of products and the fast-changing consumer demands, the possible premium paid for choosing local production is offset by the development of the country's industry, which can provide greater job creation, income, exports etc.

In addition to reserving the purchasing market to local suppliers, public procurement is also used by some countries as a tool to support the innovation of domestic companies (Aschhoff and Sofka, 2009). It should be emphasized that many innovations associated with strong social needs and demands present low private rate of return. In such cases, policies to support public procurement of an innovative nature end up representing a major vector for the development of such innovations. Therefore, taking into account that 
the markets do not always represent effective mechanisms for the satisfaction of society's needs, the public procurement policy of an innovative nature may assist in solve certain market failures, such as the absence of public goods (Edquist and Zabala-Iturriagagoitia, 2012, Georghiou et al., 2014).

\section{Efforts to measure the public procurement market: difficulties found and results achieved}

According to Audet (2003), despite the importance of public procurement and its challenges, there are few studies with the concern to quantify the market size represented by the public sector's procurement and the result of these studies cannot always be compared because they are based on different public procurement definitions. Another critical aspect regarding the measurement of the public procurement market concerns the choice of a database that ultimately allows the comparison between countries. The National Account System (NAS) of the International Monetary Fund (IMF), 1993's version, is the most used source in this type of research. NAS is universally applied in the compilation of national economic activities, despite the considerable differences in the availability of data across countries. Given the long experience of countries using the NAS, the risk of an inconsistent application or misinterpretation of its statistical definitions is considered low.

The three databases featured by the NAS definitions are: "Government Finance Statistics" of the IMF; "National Accounts Statistics: Main Aggregates and Detailed Tables" of the United Nations (UN); and “National Accounts: Detailed Tables" of the Organization for Economic Cooperation and Development (OECD). Thus, most studies conducted to measure the size of the countries' public procurement market, use either totally or partially, one of these three databases (Audet, 2003).

Although such databases exist, there are considerable differences in the availability of data across countries. Moreover, the task of measuring the size of the public procurement market becomes more complicated when attempts are made to distinguish the acquisitions made by central and subnational governments, types of expenses (consumption versus investment), or measure which portion of this market is potentially open to international trade. Audet (2003: 7) argues that: 
...the absence of detailed and consistent data about the government procurement market, broken down by levels of government, types of expenses and potentially questionable portions, represent a gap of information that needs to be filled.

According to Audet (2003), such information concerning the size of the public procurement market and in particular, its potentially questionable fractions is important for the business community, governments and trade negotiators. The importance stems from the fact that based on this information, it is possible to consider adjustments to the national and international laws that deal with this issue and identify possible violations of international laws that can be challenged at international forums (such as the WTO).

Under the Nafta Agreement, there is a chapter that deals with public procurement, which suggests that "the overall results of purchases and the number of effective hires be informed, separated by the respective signatory country the public bodies and the origin of the categories of acquired goods and services” (Guimarães, 2003: 13). However, it should be emphasized that such information is not easily accessible over the Internet. Guimarães (2003), in his effort to measure the Canadian government's procurement market (member of NAFTA), was faced with the following problems: detailed information regarding, for example, the acquisitions made by each province, can only be obtained by paying fees for the selected queries. In the case of Britain, access to input/product fiscal registers for the years prior to 1999 also occurs by means of payment. Some countries do not provide detailed information about their public procurement market, nor about their input/product matrices (Guimarães, 2003).

For many countries, the results of the bidding process by origin and category of use of goods and services are not available in a sectorial aggregated manner (Guimarães, 2003). Finally, it should be emphasized that the official statistics of certain countries are published only in their national languages, which represents an additional difficulty to the effort to measure the public procurement market in these countries.

Despite the difficulties encountered, Guimarães (2003) points out in his study the possibility of using the input-product matrix as an alternative method to measure the public procurement market of the countries. This matrix provides information about global spending broken down by economic activities, bringing to light detailed data on the 
composition of government demand. However, this author warns that the results only represent a proxy of the public procurement market, considering that the input/product matrixes work with the target of government spending, which is very different from public procurement.

In OECD (2011, 2013) reports “Government at a Glance: 2011” and “Government at a Glance: 2013", the size of public procurement markets of the member countries is estimated by using National Accounts data available in the OECD database, which is based on the NAS. These reports define public procurement as the sum of intermediate consumption (goods and services acquired by the governments, for their own use, such as information technology services, specialized consulting, etc.), gross fixed capital formation (acquisition of capital, such as the construction of ports, hospitals and new roads) and social transfers via market producers (goods and services produced by private companies, acquired by the government and supplied to households).

Based on this data and its definition, the public procurement market in OECD countries was calculated for 2011, in approximately 12\% of the GDP (on average), representing $29 \%$ of the government's total spending. Variations in this indicator, according to those responsible for preparing the reports, reflect the size of the State, its role in the economy and the existence of major public works (for example, investments in infrastructure). In 2008 in the Netherlands, Czech Republic and Iceland, government acquisitions exceeded $15 \%$ of these countries' GDP. At the other extreme, public procurement in Mexico, Chile and Switzerland represented less than 7\% of these countries' GDP in 2012 (OECD, 2013).

For some member countries, besides the expenses of the direct administration, there is also data available on the value spent with the purchases of goods and services carried out by state-owned companies. When these purchases are also recorded, the weight of the public procurement market in relation to the GDP rises to 15\%, on average (OECD, 2011). This information shows that the existence of data regarding the acquisitions of goods and services of the indirect administration increases the robustness of the public procurement market calculation, since the state-owned companies still have an important role in the economy of many countries. Finally, in the 2013 OECD report, there is also an effort to measure spending with public procurement at the state and local levels. According to this 
report, states and municipalities of the OECD member countries are responsible for 55\% of all public administration contracts, on average.

\section{Measuring the Brazilian public procurement market: methodological steps}

The measurement of the Brazilian public procurement market presented in this paper involves these steps: firstly we propose a delimitation of the Brazilian public procurement market; then we conduct a thorough investigation of existing official databases which provide longitudinal information on the public sector's budget expenditure, as well as the selection criteria adopted in the acquisition of goods and services; we then clarify our methodology to calculating the composition of public procurement activities, and finally apply the methodology to measure the Brazilian public procurement market.

\subsection{Definition and control}

The first step of the methodology presented in this paper is to define, according to the Brazilian legislation, what are the varieties and rationale of public procurement in Brazil. The study is based on Law $8.666 / 1993^{5}$, which establishes standards for the Brazilian government's tenders and contracts. This legal framework (Brazil, 1993):

... establishes general rules regarding bidding and administrative contracts relative to public works, services, including advertising, purchases, sales and leases under the powers of the federal government, states, the federal district and the municipalities.

Are subject to Law 8.666/1993 (Brazil, 1993):

... in addition to bodies of the direct administration, special funds, autarchies, public foundations, state-owned companies, joint stock companies and other entities controlled directly or indirectly by the federal government, states, the Federal District and Municipalities.

Therefore, one can perceive that the definition of purchases and the degree of underlying comprehensiveness regarding Law 8.666/93 are aligned with the definition of purchases outlined in Section 2 of this paper (since both cover the different spheres of the public sector, as well as the entities of the direct and indirect administration). In addition,

5 Available at: http://www.planalto.gov.br/ccivil_03/leis/l8666cons.htm. Accessed on 12/05/2014. 
the same can be said about the convergence of Law 8.666/93 and the methodology adopted in the OECD study, since both cover the purchases of goods and services made by bodies of indirect administration (such as state-owned companies).

After delimitation/control, the next step is to investigate the legal aspects, as well as definitions and relevant classifications relative to the country's public sector's expense budget. Therefore, this paper draws on the definitions presented in Law 4.320/64 ${ }^{6}$, which establishes general standards of financial law for the preparation and controls of the budgets and balance sheets of the federal government, states, municipalities and the Federal District. Articles 12 and 13 of this Law (Brazil, 1964), classify budget expenditure in the following economic categories: current expenses ${ }^{7}$ and capital expenses ${ }^{8}$. These two economic categories of expenditure are divided into expenditure groups, as can be seen in Figure 1. In other words, there is no specific public procurement category.

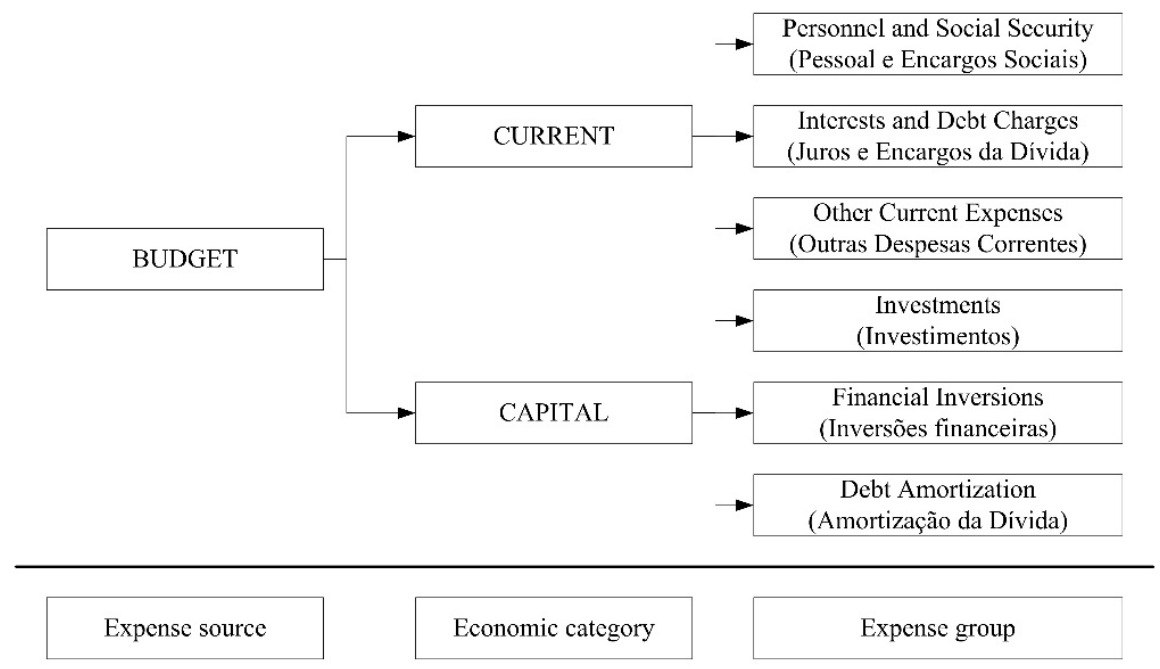

Figure 1. Budget expenditure: economic categories and expense groups

Source: Secretaria do Tesouro Nacional (2008: 54).

From Figure 1, the question that arises is as follows: in which expenditure groups

\footnotetext{
Available at: http://www.planalto.gov.br/ccivil_03/leis/14320.htm. Accessed on: 12/05/2014.

According to the National Expenditure Manual (Secretaria do Tesouro Nacional, 2008: 36), "All expenditure that do not contribute directly to the development or acquisition of a capital asset are classified in this category".

8 Capital expenditure may be conceptualized as "those expenditure that contribute directly to the development or acquisition of a capital asset” (Secretaria do Tesouro Nacional, 2008: 36).
} 
are concentrated the expenses with purchases of goods and services linked to the maintenance of the Brazilian public sector's activities? Among the six groups, two were identified with this profile: other current expenditure and investments. The other current expenditure group includes:

... budget expenditure with the acquisition of consumables, per diem payments, contributions, grants, food and transportation allowance, besides other expenses of the economic category 'Current Expenditure' not classifiable in other groups of an expenditure nature (MPOG, 2014: 54).

As to the investment group, it involves:

... budget expenditure with software and the planning and execution of works, including the acquisition of property deemed necessary to carry out the latter, and with the acquisition of facilities, equipment and permanent material (MPOG, 2014: 54).

After the definition and delimitation of the Brazilian public procurement market have been made, and the expenditure groups in which public procurement is concentrated have been identified, the focus of this study turned to the official statistics containing data on budget expenditures of the Brazilian public sector.

At first, we attempted to use the federal government's General Balance Sheet $\left(\mathrm{BGU}^{9}\right)$ to calculate the federal government's purchases. However, the reports refer to expense commitments ${ }^{10}$, which does not reflect the effective acquisitions. Given that BGU does not help in this specific quest, the research team contacted the National Treasury and was

9 The purpose of the Federal Government's General Balance Sheet is "the Accountability of the President of the Republic referring to its accounting component and as aforementioned, its drafting is the responsibility of the National Treasury, which is the central body of the Federal Accounting System, under the terms of Law No. 10.180 of February 6, 2001”. In addition to composing the Accountability of the Presidency in its printed version and also available at the CGU website, the BGU (balance sheets and statements) information will also be made available online by STN. The Federal Government's General Balance Sheet contains all Federal Government Consolidated Balance Sheets, in addition to the Financial Statements of the federal government's budget implementation, including the resources reflected in the Fiscal and Social Security Budgets in favour of the Ministries or equivalent Bodies, the Indirect Administration Entities, represented by Autarchies, Foundations, Public and Joint Stock Companies, and of the Entities established with funds of specific destination, called Special Funds.

10 Expense commitments correspond to expenses settled plus the expenses recorded in unprocessed outstanding commitments. The settlement of expenses represents the second stage of the budget expenses. It normally takes place when the Executing Units receive the object of the commitment (the material, service, asset or works). As for the unprocessed Outstanding Commitments, they are expenses committed and not settled by December $31^{\text {st }}$. 
allowed to access their database (SIAFI) for the period of 2006-2012.

One of the advantages of SIAFI Management in comparison to BGU is the fact that it separates spending with purchases of the direct and indirect administration (unlike the reports available from BGU). The tabulation of SIAFI Management data revealed a low participation of federal joint stock companies ${ }^{11}$. However, it is noteworthy that this system presents only data from state-owned and joint stock dependent companies. Based on the MPOG (2013) report, it was possible to fill this gap, for it includes data on companies and federal joint stock company purchases (both in the state-owned productive sector, as well as non-dependent official federal financial institutions).

Since Brazil is a Federation of States with more than 5,000 municipalities, it is relevant to detail that data on this level of aggregation. The states and cities level could be measured through FINBRA (Finances of Brazil), which represents the consolidation of a series of tax information sent by states and municipalities to the Secretaria do Tesouro Nacional (National Treasury). It is worth noting that the FINBRA data include the direct and indirect administration, but in aggregate form. Therefore, this database does not subdivide the states and municipalities between direct and indirect administration, contrary to what occurs in the case of the federal government.

Having defined the databases, the next task was to define which criteria would be used to calculate the Brazilian public procurement market. Table 1 briefly presents the criteria adopted.

11 For budgetary control purposes, the federal state-owned companies are divided into two groups: dependent and non-dependent. The dependent state-owned companies have their expenditures, including their investments, integrated to the Fiscal and Social Security Budget, and their schedules and budget implementations are monitored by the National Treasury - STN. The non-dependent companies on the other hand, do not receive funds from the National Treasury for the payment of expenses with personnel or with defrayment in general. Such companies are not subject to the provisions of Complementary Law No. 101 of May 4, 2000 (Fiscal Responsibility Law). 
Table 1 - Criteria used for the public procurement composition

\begin{tabular}{|c|c|c|c|c|c|}
\hline \multicolumn{2}{|c|}{ Source $\rightarrow$} & \multirow{3}{*}{$\begin{array}{c}\text { SIAFI Management } \\
\text { Federal Government }\end{array}$} & \multirow{3}{*}{$\begin{array}{c}\text { FINBRA } \\
\text { States and Municipalities }\end{array}$} & \multirow{2}{*}{\multicolumn{2}{|c|}{$\begin{array}{c}\text { MPOG } \\
\text { State-owned Companies }\end{array}$}} \\
\hline \multirow{2}{*}{ ID } & \multirow{2}{*}{ Code } & & & & \\
\hline & & & & SPE & IFOF \\
\hline 1 & & Government procurement $=(2+11)$ & PURCHASES & & \\
\hline 2 & & Procurement cost $=(3+4+5+6+7+8+9+10)$ & Procurement cost & & \\
\hline 3 & 3.3.90.30.00 & Consumables & ODCAD ${ }^{4}$ Consumables & Material and Products & Rental Equipment + DP ${ }^{3}$ \\
\hline 4 & 3.3.90.32.00 & Free Distribution Material & ODCAD Free Distribution Material & & \\
\hline 5 & 3.3.90.33.00 & Travel Fare and Expenses & ODCAD Travel Fare and Expenses & & \\
\hline 6 & 3.3.90.35.00 & Consulting Services & ODCAD Consulting Services & & \\
\hline 7 & 3.3.90.36.00 & Other Third-Party Services - Individuals & ODCAD Other Third-Party Services - Individuals & Third_nartv Services & Third_narty Services \\
\hline 8 & 3.3.90.39.00 & Other Third-Party Services - Corporate & ODCAD Other Third-Party Services - Corporate & 17iru-party services & 1mIru-party services \\
\hline 9 & 3.3.90.37.00 & Labour Leasing & ODCAD Labour Leasing & & \\
\hline 10 & 3.3.90.38.00 & Commercial Leasing & ODCAD Commercial Leasing & & \\
\hline 11 & & Purchases of Capital Assets $=(12+13)$ & Capital PURCHASES & & \\
\hline 12 & 4.4.90.51.00 & Works and Facilities & Investments ${ }^{1}$ & Investments $^{1}$ & Investments $^{2}$ \\
\hline 13 & 4.4.90.52.00 & Equipment and Permanent Material & investments & mvestments & minestiments \\
\hline
\end{tabular}

Sources: SIAFI Management (2006-2012), FINBRA (2006-2012) and MPOG (2013, 2014).

Notes: 1 FINBRA did not disaggregate spending on investments, which in municipalities is mostly composed by Works and Facilities (4490.51) and Equipment and Permanent Material (4490.52).

2 Includes Commercial Leasing operations.

$3 \mathrm{DP}=$ data processing

4 ODCAD = Other Current Expenditure Direct Application = Outras Despesas Correntes Aplicação Direta. 
As seen in Table 1, the items referring to expenses associated to purchases are divided into procurement cost (linked to the current expenditure economic category) and capital purchases (linked to capital expenses economic category). From the analysis in Table 1 it is possible to notice that in the case of the federal government, states and municipalities the same items were practically used, except for capital purchases, since the databases adopted to measure the federal government's procurement market (SIAFI Management) divide the purchases linked to capital expenditures in "works and facilities" and "equipment and permanent material”, while for FINBRA, these purchases are included in "investments".

Finally, regarding the last two columns of Table 1, as previously emphasized, SIAFI Management does not provide data about the so-called non-dependent companies. Therefore, this study drew from MPOG report data (2006-2012), which deals with the budgetary implementation of the non-dependent state-owned companies. The MPOG reports contain statistics on the state-owned productive sector (SPE) in the penultimate column and the official federal financial institutions (IFOF) in the last column. From the tabulations presented in the MPOG report, which contains data on current and capital expenditures, the following criteria referring to purchases were identified: "materials and products", "third-party services” and "investments" for the SPE; and, "equipment lease and data processing”, "third-party services" and "investments" for the IFOFs.

\subsection{Application}

This section applies the previously designed approach to outline the direct and indirect administration purchases linked to the federal government, as shown in Table 2. 
Table 2 - Public procurement of Federal government

(in $R \$$ billion-current prices)

\begin{tabular}{|c|c|c|c|c|c|c|c|c|c|c|c|c|c|c|c|}
\hline \multirow[t]{6}{*}{ Source $\rightarrow$} & \multicolumn{4}{|c|}{ SIAFI Management } & \multicolumn{8}{|c|}{ MPOG } & \multirow{5}{*}{\multicolumn{2}{|c|}{ Total }} & \multirow{6}{*}{ GDP } \\
\hline & \multicolumn{2}{|c|}{ Direct } & \multicolumn{10}{|c|}{ Indirect $^{1}$} & & & \\
\hline & & & \multirow{3}{*}{\multicolumn{2}{|c|}{$\begin{array}{c}\text { Bodies of the } \\
\text { Indirect } \\
\text { administration and } \\
\text { dependent state- } \\
\text { owned companies }\end{array}$}} & \multirow{2}{*}{\multicolumn{6}{|c|}{$\begin{array}{c}\text { State-owned Productive Sector -SPE } \\
\text { Non-dependent }^{3}\end{array}$}} & \multirow{3}{*}{\multicolumn{2}{|c|}{ IFOF $^{4}$}} & & & \\
\hline & & & & & & & & & & & & & & & \\
\hline & & & & & \multicolumn{2}{|c|}{ Petrobras Group } & \multicolumn{2}{|c|}{ Eletrobras Group } & \multicolumn{2}{|c|}{ Others } & & & & & \\
\hline & Value & $\% /$ GDP & Value & $\% / G D P$ & Value & \%/GDP & Value & $\% / G D P$ & Value & \%/GDP & Value & \%/GDP & $\mathbf{R} \$$ & $\% / G D P$ & \\
\hline 2006 & 20 & .8 & 20 & .9 & 98 & 4.1 & 17 & .7 & 7 & .3 & 14 & .6 & 176 & 7.4 & 2,369 \\
\hline 2007 & 18 & .7 & 19 & .7 & 118 & 4.4 & 18 & .7 & 8 & .3 & 13 & .5 & 194 & 7.3 & 2,661 \\
\hline 2008 & 20 & .7 & 20 & .7 & 155 & 5.1 & 22 & .7 & 8 & .3 & 16 & .5 & 242 & 8.0 & 3,032 \\
\hline 2009 & 23 & .7 & 27 & .8 & 155 & 4.8 & 21 & .6 & 10 & .3 & 17 & .5 & 253 & 7.8 & 3,239 \\
\hline 2010 & 30 & .8 & 35 & .9 & 188 & 5.0 & 23 & .6 & 11 & .3 & 17 & .4 & 305 & 8.1 & 3,770 \\
\hline 2011 & 29 & .7 & 32 & .8 & 190 & 4.6 & 26 & .6 & 13 & .3 & 19 & .5 & 309 & 7.5 & 4,143 \\
\hline 2012 & 32 & .7 & 32 & .7 & 251 & 5.7 & 29 & .7 & 15 & .3 & 23 & .5 & 381 & 8.7 & 4,392 \\
\hline $\begin{array}{c}\text { Total } \\
\text { Average }\end{array}$ & 173 & .7 & 185 & .8 & 1,155 & 4.9 & 157 & .7 & 72 & .3 & 118 & .5 & 1,861 & 7.9 & 23,608 \\
\hline
\end{tabular}

Source: SIAFI Management (2006 to 2012); MPOG (2013, 2014).

Notes: 1 Sum of the indirect federal administration bodies, including state-owned companies (dependent and non-dependent).

2 According to art. 2, item III, of complementary law No. 101, of January 4, 2000, the dependent state-owned companies are controlled by the federal government, which receive funds from the National

Treasury for the payment of expenses with personnel, general or capital expenditures, excluded in the latter case, those from shareholding increase. According to art. 2, item III of Complementary Law No. 101 of January 4, 2000, the dependent state-owned companies are controlled by the federal government, which receive funds from the National Treasury for the payment of expenses with personnel, general or capital expenditures, excluded in the latter case, those from shareholding increase. A few examples are: Centro Nacional de Technology Eletrônica Avançada S.A. - CEITEC; Brazilian Urban Train Company CBTU; National Supply Company - CONAB; and the Brazilian Agricultural and Livestock Research Company - EMBRAPA. For a complete list see the 2013 Annual Report: budgetary implementation of state-owned companies Base Year of 2012 (MPOG, 2013: 14). On the other hand, the other federal government bodies, part of the indirect administration, which are dependent, are the following: Autarchies, Foundations, State-owned Commercial and Financial companies, Mixed Economies and Funds.

3 State-owned non-dependent companies are those controlled by the federal government that DO NOT receive funds from the National Treasury for the payment of expenses with personnel, general or capital expenditures.

4 Official federal financial institutions.

Prepared by the authors. 
Within the federal government, it is possible to observe a large participation of the indirect administration in comparison to the direct administration. For the period between 2006 and 2012, while the federal direct administration expenditures represented on average $0.7 \%$ of the GDP, the expenses with acquisitions of goods and services by the federal indirect administration reached a value equivalent to $7.2 \%$ of the GDP. At this point, it is worth emphasizing the weight of the non-dependent stateowned company's productive sector and particularly, the magnitude of the acquisitions made by Petrobras. For the federal government, its spending on the purchase of goods and services took up on average $7.9 \%$ of the GDP for the period analysed, while the spending of Petrobras alone took up 4.9\% of the GDP. Accordingly, the important role assumed by this company is noteworthy, since it contributes with over half the federal government spending on purchases of goods, services and works.

The data also made possible the separation between federal, state and municipalities (Table 3).

Table 3 - Public procurement of Brazil, second entity

\begin{tabular}{|c|c|c|c|c|c|c|c|c|c|}
\hline \multirow[t]{2}{*}{ Year } & \multicolumn{2}{|c|}{$\begin{array}{c}\text { Federal } \\
\text { government }^{1}\end{array}$} & \multicolumn{2}{|c|}{ State $^{2}$} & \multicolumn{2}{|c|}{ Municipalities ${ }^{2}$} & \multicolumn{2}{|c|}{ Total } & \multirow[t]{2}{*}{ GDP } \\
\hline & Value & $\% /$ GDP & Value & $\% /$ GDP & Value & $\% / \mathrm{GDP}$ & $\mathrm{R} \$$ & $\%$ GDP & \\
\hline 2006 & 176 & 7.4 & 59 & 2.5 & 85 & 3.6 & 320 & 13.5 & 2,369 \\
\hline 2007 & 194 & 7.3 & 58 & 2.2 & 96 & 3.6 & 347 & 13.0 & 2,661 \\
\hline 2008 & 242 & 8.0 & 76 & 2.5 & 117 & 3.9 & 436 & 14.4 & 3,032 \\
\hline 2009 & 253 & 7.8 & 88 & 2.7 & 103 & 3.2 & 444 & 13.7 & 3,239 \\
\hline 2010 & 305 & 8.1 & 103 & 2.7 & 121 & 3.2 & 529 & 14.0 & 3,770 \\
\hline 2011 & 309 & 7.5 & 92 & 2.2 & 141 & 3.4 & 542 & 13.1 & 4,143 \\
\hline 2012 & 381 & 8.7 & 94 & 2.1 & 161 & 3.7 & 637 & 14.5 & 4,392 \\
\hline $\begin{array}{c}\text { Total } \\
\text { Average }\end{array}$ & 1,861 & 7.9 & 571 & 2.4 & 823 & 3.5 & 3,255 & 13.8 & 23,608 \\
\hline
\end{tabular}

Source: $\quad{ }^{1}$ MPOG (2013 and 2014). SIAFI Management (2006-2012). See Table 2 column Total.

2 FINBRA (2006-2012).

Notes: Prepared by the authors.

From Table 3 we can conclude that the federal government is the largest buyer in Brazil, (average of 7.9\%), followed by the municipalities (average of 3.5\%) and by the states (average of 2.4\%). Table 3 also shows that in the year of 2012 Brazilian public procurement market represented $14.5 \%$ of its GDP. Finally, it should be noted that Brazilian reality is different from OECD member countries. As to OECD countries, we observe the opposite that the federal government is not the main buyer. However, it is worth noting once again, that the expressive volume of purchases made by Petrobras 
greatly increases the federal government's purchases. The presence of such a dominant state-owned oil company in Brazil is certainly not repeated in most OECD member countries.

Chart 1 was made to better present the weight of the Brazilian public procurement market as a whole, as well as the three levels of the federation.

\section{Chart 1 - Public procurement of Brazil}

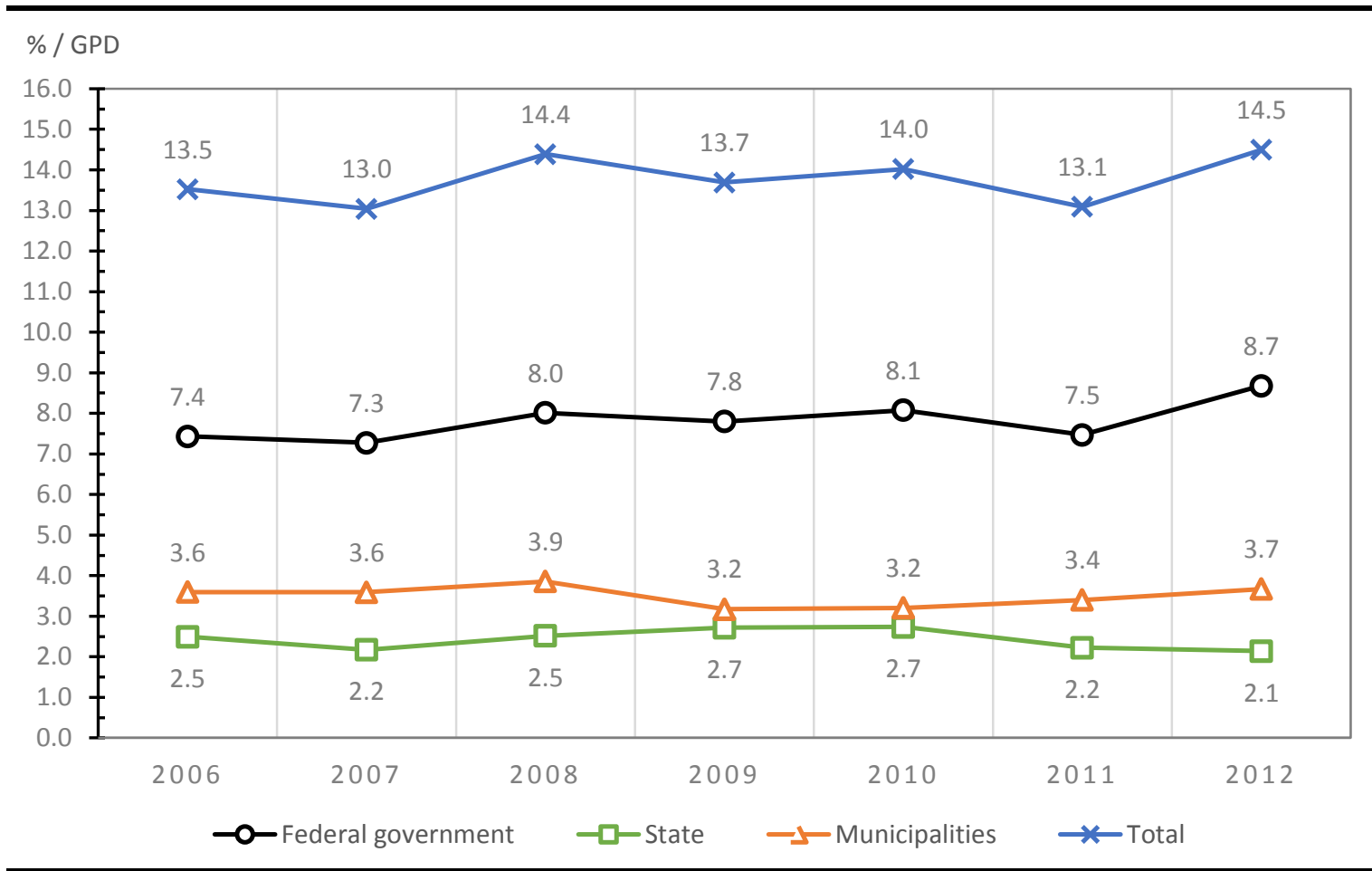

Source: $\quad$ SIAFI Management (2006-2012), MPOG (2013, 2014) and FINBRA (2006-2012).

Notes: $\quad$ Prepared by the authors.

We can conclude from Chart 1 that the weight of the public procurement market in comparison to the GDP, including all branches and entities of the Brazilian public sector, is quite significant. For the period analysed, this weight was never below two digits, with $13.0 \%$ in 2007 and peaking at $14.5 \%$ in 2012. This demonstrates that the size of the Brazilian public procurement market is comparable to the size of the procurement market of a typical OECD country.

For the three federation entities, it is possible to verify certain stability in the weight of its procurement market between 2006 and 2012. However, it is worth noting that a leap occurred in federal government purchases between 2011 and 2012, from $7.5 \%$ to $8.7 \%$. This leap was largely due to anticyclical macroeconomic policy carried 
out by the Federal Government and also to the increase in Petrobras purchases (in fact an instrument of this policy); during this same period, the Brazilian oil company's purchases/GDP indicator went from $4.6 \%$ to $5.7 \%$.

Another possible analysis from the data collected to measure the Brazilian public procurement market was the separation between investment procurement and current expenses procurement

Table 4 - Nature of Public Procurement of Brazil, according to Other Current Expenses (OGC) and Investment (AKF), in percentage of the total

\begin{tabular}{c|cc|cc|cc||cc}
\hline \multirow{2}{*}{ Year } & \multicolumn{2}{|c|}{$\begin{array}{c}\text { Federal }^{2} \\
\text { government }\end{array}$} & \multicolumn{2}{|c||}{ State $^{\mathbf{2}}$} & \multicolumn{2}{c||}{ Municipalities $^{2}$} & \multicolumn{2}{c}{ Total $^{2}$} \\
& OGC & AKF & OGC & AKF & OGC & AKF & OGC & AKF \\
\hline 2006 & 68 & 32 & 73 & 27 & 76 & 24 & 71 & 29 \\
2007 & 70 & 30 & 77 & 23 & 76 & 24 & 73 & 27 \\
2008 & 70 & 30 & 71 & 29 & 72 & 28 & 71 & 29 \\
2009 & 61 & 39 & 66 & 34 & 80 & 20 & 67 & 33 \\
2010 & 60 & 40 & 63 & 37 & 77 & 23 & 65 & 35 \\
2011 & 63 & 37 & 72 & 28 & 77 & 23 & 68 & 32 \\
2012 & 65 & 35 & 78 & 22 & 75 & 25 & 70 & 30 \\
\hline \hline Average & 65 & 31 & 29 & 76 & 24 & 69 & 31 \\
\hline
\end{tabular}

As shown in the table, the patterns across the federal government, states and municipalities appeared to be very similar. With all entities taken into account, the spending associated to 'other current expenses' represented an average of $69 \%$ of the Brazilian public sector's purchases over the period analysed, with the remaining 31\% linked to investment purchases. The federal government is, among the three types of entities, the one with the largest volume of acquisitions associated to investments (with $35 \%$ on average). This is quite expected, since the main infrastructure investments in Brazil are made by the Federal government.

\subsection{Discussion}

The primary objective of public procurement is the provision of goods and services necessary for the realization of government missions to society. As government purchases represent an important part of the public sector budget, funded largely with 
funds from taxpayers, it is expected that governments carried out procurement activities efficiently, with a high standard of conduct, safeguarding the public interest (OECD, 2015). In this sense, monitoring the evolution of this market and the availability of detailed data could assist the government in identifying excesses, contributing to public resource savings and the reallocation of resources.

Based on the conceptual perspectives presented in the paper section 2 as well as the contributions of Thai, the availability of data on spending on government procurement can help the public sector in the ex-post evaluation of procurement policy with regard to issues of cost and integrity. As noted in section 2, corruption associated with procurement processes of goods and services, such as overpricing in public works and the payment of bribes, is a scourge that affects the global public administration. Specifically, in Brazil, recently came to light corruption scandals that brought severe damage to Petrobras.

In this sense, government procurement should be subject to constant monitoring by the control agencies, in order to detect and inhibit illegal practices. The importance of constant monitoring of the acquisitions made by the public sector stems largely from the difficulty present in many cases, to measure the damage that corruption in public procurement causes to the State coffers.

The argument is that the availability of data about public procurement enriches the assessment phase that make up the cycle of public policies carried out by the State bureaucracy. It is asking the impact of deficits and unwanted side effects in order to deduce consequences for actions and programs. Thus, the assessment phase is essential for the development and continuous adaptation of forms and instruments of public action. The evaluation of public procurement policies can enhance accountability to society, detect problems in adopted mechanisms and when necessary, make changes to the legal framework governing public sector procurement.

With regard to non-procurement goals such as economic, social, industrial and technological, it is important to note that the measurement presented in this study indicates that we are facing a market whose size (relative to GDP) is comparable to OECD countries. For the period analyzed, this weight was never below two digits. Public procurement took up an average of 13.8\% of the GDP from 2006 to 2012. This led to an enormous leveraging power, which can be used to achieve non-procurement goals.

The first step in the evaluation of non-procurement goals is precisely monitoring, 
which could offer more details on the Brazilian state spending on the purchase of goods and services. From this information, with the use of qualitative and quantitative tools, it is possible to think of efforts to causal attribution and the investigation of issues such as: i) what are the connections between indicators such as employment, industrial productivity, innovation and the public procurement expenditure?; ii) what findings can be drawn in relation to the composition of purchases associated with the acquisition of fixed capital and purchases linked to current spending?

It is worth mentioning that the Brazilian economy is faced today with some challenges that need to be overcome for the country to resume its path toward a more solid development process. There are studies that point to the existence of problems such as deindustrialization and reprimarization of the country's economy (BresserPereira, 2008). Specifically, in relation to deindustrialization, such a process is distinct from the one that occurs in developed countries, because it is a process of premature deindustrialization which happens without the country has exhausted the potential of industrialization process (such as increased productivity and irradiation of the technical progress).

From the point of view of the Brazilian industrial park, the data indicate that such park suffers from some problems, such as low technological capability of their companies and a strong presence of foreign capital firms in the noblest industries. Because of these problems, the country has a great reliance on technology and higher value-added components imported. Furthermore, the scenario in the screen manifests itself also in the balance of payments of the country: persistently negative balances in accounts such as remittance of profits abroad and royalty.

Assuming that the convergence between countries with different levels of development should not be seen as a natural process associated with the logic of the market, the state plays a decisive role in the development of a country (Chang, 2002, Lall, 1992). In this sense, looking at the problems faced by Brazilian industry, it is worth highlighting the importance of a development plan to rescind, or reverse these perverse tendencies. According to findings from the literature on public procurement as a multifunctional policy, as well as data presented in the previous section, one of the mechanisms that the Brazilian government should focus on is precisely using public procurement to achieve various policy objectives. Its magnitude and impacts of this policy in several areas by itself justify the strategic role that it should assume in the development agenda adopted by the Brazilian Government. 
The potential of utilizing public procurement to promote innovation in Brazil, for example, is still subject to dedicated exploration, especially given the fact that there is a wide range of concrete policy instruments that might be adoptable. Considering the need to create more effective mechanisms to connect the R\&D with production and market needs in developing countries (Development Policy Review, 1970), it is worth stressing the important role (to be further explored in Brazil) of the Public Procurement for Innovation (PPI). PPI is an important policy to encourage R\&D, due to the ability of the State to take risks and its great purchasing power (Edler and Georghiou, 2007).

Being one of the largest emerging economies, Brazil might well find it useful to learn from the Chinese experience of promoting indigenous innovation through public procurement. Firstly, launched in 2006 as one of the new innovation policy instruments included in the Guideline on National Medium- and Long-term Program for Science and Technology Development (2006-2020), public procurement of innovation policies used to be held at high profile during 2007-2011 (Li and Georghiou, 2016). Several policy approaches were put in place at both national and regional levels, including those focused on bridging the supply and demand sides through product catalogues (ibid.), as well as those in the form of sectoral demonstration programs for newly developed local technologies (Li et al., 2015).

Those policies featured an explicit focus on import substitution, national protectionism and catching up, which drew severe concerns from international trade partners such as the US and EU. This tension eventually led to the termination of core procurement of innovation policies. This experience offers important lessons for Brazil - how should domestic procurement policies be aligned with international trade interests? How can developing countries exercise sophisticated procurement policies to best serve their interests in this context of globalization? Besides those issues related to the external environment, Li and Georghiou (Li and Georghiou, 2016) also highlighted internal issues hindering the use of public procurement in China such as institutional and capability failures.

Romijn and Caniëls (2011) emphasize the importance of a strategic reorientation in relation to the technological advancement of developing countries. According to the authors technological accumulation strategies focused on assimilation and catch-up of Western technological frontiers have limitations in the current era, which is characterized by challenges in themes such as resource depletion, energy and water supply and environmental degradation Therefore, it is becoming evident that developing 
countries - mainly large countries like China, Brazil and India - “will need to do better than Western ones if they are to attain development levels similar to current developedcountry standards” (Romijn and Caniëls, 2011: 365). In relation to Brazil, country characterized by a strong presence of State-Owned Enterprises in the sectors of oil, energy, and water and sewage and abundant in natural resources, it is evident the potential represented by the adoption of PPI to the generation of technologies do not put in danger the finite natural resources and the absorption capacity of the planet.

In particular, it highlights the importance of the oil sector to the Brazilian economy, as well as the weight of Petrobras under the government procurement policy of the country. Expenditures of State Oil Company with purchases of goods and services represented $4.9 \%$ of the GDP for the period investigated. This company, since its inception has assumed an important role in the Brazilian context, whether from the point of view of reducing the country's dependence on imports of hydrocarbons, or with regard to the development of the capital goods industry. From the beginning of the 2000s, Petrobras started to adopt a purchasing policy with local content requirements. This strategy, although it contains some gaps as timid attention to the technological development of local suppliers (Ribeiro and Furtado, 2014), brought interesting results such as job creation, attracting foreign companies to the country and strengthening the supply chain of equipment and services for the oil industry.

With the discovery of deposits in the pre-salt layer, there are great opportunities and challenges for the Brazilian oil industry. Exploratory research indicated that the presalt reservoirs have potential to elevate the Brazilian reserves from the current 14 billion barrels, to about 80 billion, making Brazil a major producer of hydrocarbons in the world. Despite the enormous economic potential of the reserves located in this new oil frontier, the number of technological obstacles (such as logistics, geology and environmental protection) to be overcome to enable hydrocarbon production is significant. Therefore, it can be said that the pre-salt, due to the opportunities and challenges that result from it, is a turning point from which Brazil can emerge not only as a major oil producer, but also as a developer of offshore technologies. It is worth mentioning that the regulatory framework for pre-salt area provides that Petrobras will be the sole operator of the blocks, that is, responsible for drilling and operating the wells. In this sense, it is perfectly clear that Petrobras' procurement activities have great implications on the overall development of Brazil. 


\section{Conclusions}

As pointed out in the article, there are few studies in Brazil that aim to measure the country's public procurement market. The purpose of this paper was to address this gap identified in the literature by presenting, in detail, a methodology to measure the country's public procurement market based on official statistics. This methodology includes the three levels of government. Moreover, in the federal government's case, the existing databases allowed the separation of the direct and indirect administration.

In summary, the main conclusion that extracts of the study about the public procurement policy is that the State, by means of this policy instrument, can encourage strategic sectors, thus promoting domestic industries. Despite the possible initial extra costs associated with the purchase of locally produced goods and services, the development of enterprises of the country provided by public procurement compensates for such a burden.

Depending on the industrial and technological policies agenda and strategic objectives of the Government, the use of discriminatory measures in relation to foreign suppliers can assume an important role in supporting the technological development of firms in a country. There are a number of empirical research that indicate that the Government procurement policy can be an important instrument, although not exclusively, to the promotion of development of a country.

Given that public sector acquisitions play a significant role in national economies, the relevance of complete and detailed data about the public procurement market stands out. An accurate account of the public procurement market can support the public sector's decision making process and bring information and data to light. Moreover, the measurement of the public procurement market can offer transferrable lessons for similar studies in the future. A robust measurement methodology for the public procurement market should include both the direct and indirect administration since the entities linked to the State, such as public and mixed capital companies, make important acquisitions, which are subject to the laws that rule purchases made by government bodies.

Based on the presented data it was possible to demonstrate the importance of public procurement policy in the Brazilian context. It is a market with a magnitude (as a proportion of domestic GDP) comparable to OECD countries. This information 
corroborates the data presented by other studies relative to the size of the public sector's procurement market and show the importance of this policy in the national context. Therefore, we emphasize here the relevance of the methodology presented in this article, since it provides subsidies that can be used by other studies on the same topic.

\section{References}

1970. 7 The Role of Science and Technology in Development. Development Policy Review, A4, 68-79.

ARROWSMITH, S. 2010. Public Procurement: basic concepts and the coverage of procurement rules. In: ARROWSMITH, S., TREUMER, S. \& FEJØ, J. (eds.) Public Procurement Regulation: An Introduction. Nottingham, UK: The EU Asia Inter University Network for Teaching and Research in Public Procurement Regulation.

ASCHHOFF, B. \& SOFKA, W. 2009. Innovation on demand-Can public procurement drive market success of innovations? Research Policy, 38, 1235-1247.

AUDET, D. 2003. Government procurement: A synthesis report. OECD Journal on Budgeting, 2, 149-194.

BRASIL, Lei ${ }^{\circ}$ 8.666, de 21 de junho de 1993. Regulamenta o artigo 37, inciso XXI, da Constituição Federal, institui normas para licitações e contratos da Administração Pública na Administração Pública e dá outras providências. Available at: <http://www.planalto.gov.br/ccivil_03/leis/L8666cons.htm>. Accessed: 15. mar. 2007.

BRASIL. Lei $\mathrm{n}^{\circ}$ 4.320, de 17 de março de 1964. Estatui Normas Gerais de Direito Financeiro para elaboração e controle dos orçamentos e balanços da União, dos Estados, dos Municípios e do Distrito Federal. Available at: < http://www.planalto.gov.br/ccivil_03/leis/14320.htm>. Accessed: 15. mar. 2007.

BRESSER-PEREIRA, L. C. 2008. The Dutch disease and its neutralization: a Ricardian approach. Revista de Economia Política, 28, 47-71.

CHANG, H.-J. 2002. Kicking away the ladder: development strategy in historical perspective, London, Anthem Press.

EDLER, J. \& GEORGHIOU, L. 2007. Public procurement and innovationResurrecting the demand side. Research Policy, 36, 949-963.

EDQUIST, C. \& ZABALA-ITURRIAGAGOITIA, J. M. 2012. Public Procurement for Innovation as mission-oriented innovation policy. Research Policy, 41, 17571769.

EDQUIST, C., VONORTAS, N. S. \& ZABALA-ITURRIAGAGOITIA, J. M. 2015. Introduction. In: EDQUIST, C., VONORTAS, N. S., ZABALAITURRIAGAGOITIA, J. M. \& EDLER, J. (eds.) Public procurement for innovation. Cheltenham, UK: Edward Elgar Publishing.

GEORGHIOU, L., EDLER, J., UYARRA, E. \& YEOW, J. 2014. Policy instruments for public procurement of innovation: Choice, design and assessment. Technological Forecasting and Social Change, 86, 1-12.

GUIMARÃES, E. P. 2003. Compras governamentais por parte dos Estados Unidos, Canadá e União Européia: uma avaliação exploratória da possibilidade de 
quantificação. Texto para Discussão No 943 [Online]. Available: http://www.ipea.gov.br/portal/images/stories/PDFs/TDs/td_0943.pdf.

KASHAP, S. Public Procurement as a Social, Economic and Political Policy. International Public Procurement Conference, 2004 Fort Lauderdale, Florida, USA. 133-147.

LALL, S. 1992. Technological capabilities and industrialization. World Development, 2, 165-186.

LI, Y. \& GEORGHIOU, L. 2016. Signaling and accrediting new technology: Use of procurement for innovation in China. Science and Public Policy, 43, 338-351.

LI, Y., GEORGHIOU, L. \& RIGBY, J. 2015. Public procurement for innovation elements in the Chinese new energy vehicles program. In: EDQUIST, C., VONORTAS, N. S., ZABALA-ITURRIAGAGOITIA, J. M. \& EDLER, J. (eds.) Public Procurement for Innovation. Cheltenham: Edward Elgar Publishing.

MARQUES, F. S. 2005. Compras Públicas no Brasil e EUA: análise da concorrência segundo o paradigma estrutura-conduta-desempenho. Monografia premiada em $3^{\circ}$ lugar no X Prêmio Tesouro Nacional - 2005, Tópicos Especiais de Finanças Públicas [Online]. Available: http://www3.tesouro.fazenda.gov.br/Premio_TN/XPremio/financas/3tefpXPTN/ 3pemio_tefp.pdf [Accessed 14 out. 2008].

MENDOZA, R. U. \& THELEN, N. 2008. Innovations to Make Markets More Inclusive for the Poor. Development Policy Review, 26, 427-458.

MINISTÉRIO DO PLANEJAMENTO, ORÇAMENTO E GESTÃO (MPOG). Manual técnico de orçamento. Brasília, Edição 2014 ( $1^{\text {a }}$ versão). Available at: < http://www.orcamentofederal.gov.br/informacoes-orcamentarias/manualtecnico/MTO_2014.pdf>. Accessed: 10 out. 2014.

MINISTÉRIO DO PLANEJAMENTO, ORÇAMENTO E GESTÃO. Execução orçamentárias das empresas estatais. Brasília, Edição 2013 (ano base 2012). Available at:

http://www.planejamento.gov.br/secretarias/upload/Arquivos/dest/relatorio_an ual/2012/Relatorio_2013_ano_base_2012_2.pdf >. Accessed: 18 set. 2014.

OCDE 2010. Collusion and Corruption in Public Procurement. Paris: OECD.

OECD 2011. Government at a Glance 2011, Paris, OECD Publishing.

OECD 2013. Government at a Glance 2013, Paris, OECD Publishing.

OECD 2015. Government at a Glance 2015, Paris, OECD Publishing.

RIBEIRO, C. G. \& FURTADO, A. T. 2014. Government Procurement Policy in Developing Countries: The Case of Petrobras. Science Technology \& Society, 19, 161-197.

RIBEIRO, C. G. 2009. Compras governamentais e aprendizagem tecnológica: uma análise da política de compras da Petrobras para seus empreendimentos offshore. Doctorade, Universidade Estadual de Campinas - UNICAMP.

ROMIJN, H. A. \& CANIËLS, M. C. J. 2011. Pathways of Technological Change in Developing Countries: Review and New Agenda. Development Policy Review, 29, 359-380.

SECRETARIA DO TESOURO NACIONAL. Manual De Despesa Nacional. $1^{\mathrm{a}}$ Edição. Portaria Conjunta STN/SOF $n^{0}$ 3, de 2008. Available at: < http://www.sefaz.al.gov.br/legislacao/Financeira/federal/MANUAL_DESP_N ACIONAL.pdf>. Accessed: 10 out. 2014.

THAI, K. V. 2001. Public Procurement Re-examined. Journal of Public Procurement, 1, 9-50. 
THAI, K. V. 2009. International Public Procurement: Concepts and practices. In: THAI, K. V. (ed.) International handbook of public procurement. Boca Raton, FL Auerbach Publications. 